\title{
THE REALITY OF THE PRACTICE OF STRATEGIC MANAGEMENT TECHNIQUES FOR PALESTINIAN INDUSTRIAL CORPORATIONS AND SPECIALISTS ON THE ROLE AND IMPACT THEY PLAY
}

\author{
Dr. Eitedal M. S. Alhelou ${ }^{1 *}$, Dr. Iskandar M. H. Nashwan ${ }^{2}$, Dr. Issam M. A. AL TaweeL ${ }^{3}$, Dr. Yarob J. \\ Kullab $^{4}$ \\ ${ }^{*}$ Assistant Professor, Department of Accounting, Faculty of Financial and Business Administration, Palestine \\ University-Gaza-Palestine e_alhelo@yahoo.com \\ ${ }^{2}$ Associate Professor, Department of Accounting, Faculty of Management and Finance, Al-Aqsa University Gaza \\ dr.eskandar.n@gmail.com \\ ${ }^{3}$ Associate Professor, Department of Accounting, Faculty of Management and Finance, Al-Aqsa University Gaza \\ imat1976@hotmail.com \\ ${ }^{4}$ Assistant Professor, Department of Accounting, Faculty of Management and Finance, Al-Aqsa University Gaza \\ yj.kolab@alaqsa.edu.ps
}

*Corresponding Author: -

Email: e_alhelo@yahoo.com

\begin{abstract}
: -
The study aimed primarily to examine the reality of the practice of strategic management techniques for Palestinian industrial enterprises and the guidance of specialists on the role and impact they play and to achieve this. The study concluded that industrialized enterprises in the Gaza Strip attached great attention to strategic administrative accounting techniques and their use in cost accounting, oversight and performance measurement, competitors' accounting, and strategic decision-making, but still require further strengthening and guidance. The strategic administrative accounting techniques play an important role in the perspective of industrialized companies. Study the need for partners using modern methods of management accounting and performance evaluation, leading to new measurement methods related to customer's satisfaction, preservation and satisfaction of employees and developing their skills as basic factors to assess how these companies work and to develop management accounting techniques to suit its philosophy and objectives with modern requirements Industrial, technological, environmental and economic. Palestinian industrial enterprises can be competitive and continuity.
\end{abstract}

Keywords: - Management accounting techniques, strategic management accounting, and specialized orientations.

\section{(우 (\$) (1)}




\section{INTRODUCTION:}

The global openness and broken international barriers led to the development of economic and industrial economic environment, especially and competition in the administrative instruments of the advanced and industrial environment, which was summoned to develop the administrative methods to suit its philosophy and objectives with the modern requirements of the industrial and economic environment taken from the cost management. They have a successor to analyze cost which is a curriculum representing financial and non-financial information that enables the institution to compete and continuity.

In parallel with environmental changes surrounding the accounting system of super-technological developments and the information revolution, has increased the need for strategic information on customers and competitors. The weakness of the conventional methods of management accounting and performance evaluation has appeared. That led to the creation of new measurement methods relating to customer's satisfaction, preservation and development of employees and developing their skills as basic factors to assess how institutions work (Al Ani, 2015), and to assist the information provided by the strategic management accounting for general support and financial reports in particular requires the use of the strategic management tools supported by those reports such as internal and external environmental assessment tools, strategic management support tools, and company performance support tools (Al Rabiaa, 2018). The strategic management accounting for transition from operational issues has focused on strategic oriented issues through the integration of operations of financial and human resources, which has made an essential role in the strategic decision-making process (Hisham, 2013).

The problem is determined by the following questions:

1. What is the level of practicing Palestinian industrial companies for strategic management technologies?

2. What role and impact are played by strategic management techniques if they are applied according to the perspective of specialists in Palestinian industrial companies?

Objectives of the study:

This study aims at examining the reality of the practice of strategic management techniques for Palestinian industrial enterprises and its course orientations on the role and impact they play, by achieving the following objectives:

1. Statement of the practice of industrial companies for strategic management technologies?

2. Determine the role played by strategic management techniques and impact that can be left in industrial companies from the point of view of specialists?

3. Highlight the important subject and enriched Arab library and researchers.

4. The importance of study:

5. The importance of the study is:

6. This study is in addition to accounting studies in administrative accounting.

7. The importance of this study stems from the importance of the subject, where the strategic management techniques are one of the most important tools of success companies and institutions.

8. Emphasize the importance of strategic management techniques to achieve important significant mistakes and can be accredited in Palestinian industrial companies.

\section{Study hypotheses:}

Based on the problem of study, the main question and its specific objectives, the following assumptions were formulated:

The first hypothesis: Palestinian industrial enterprises do not exercise strategic management techniques at a relative weight of $60 \%$ and less.

Second Hypothesis: Strategic Management Accounting Techniques Do not play any role or impact according to the perspective of specialists in industrial companies at a relative weight of $60 \%$ and less.

\section{Limitations of the study: The limits of the study are:}

Spatial boundaries: The spatial boundaries of this study in Palestinian industrial companies in the Gaza Strip were represented.

Human boundaries: The human limits for this study are all specialists and researchers believe that specialists are in (financial managers and accountants working in the production department of companies, as well as decisions from higher levels) in Palestinian industrial companies.

The time boundaries: Field study is expected from May until the end of August 2020.

Previous Arab and Foreign Studies:

A group of Arab and foreign studies has been complementary to theoretical framework for the study, and will be displayed from the latest to the oldest as follows:

* Study of (Altarawneh, 2021) aims to learn the impact of the SMATS to achieve the competitive advantage (CA) in Jordanian General Industrial Companies and to achieve the objectives of the study, the used the analytical descriptive approach, social surveys and the preparation and distribution of questionnaires on all financial managers in Jordanian industrialized companies. The study concluded with many results: - The SMATS level in 
Jordanian public companies was high. The level of competitive advantages in Jordanian public industrial companies was high. There was an effect for SMATS to achieve competitive advantage, where it explains (66.1\%) of the contrast in achieving competitive advantage. The study recommended that a modern technological environment should be provided to link modern accounting systems with various accounting systems in Jordanian industrial companies, conducting studies and research in advanced methods and modern systems for strategic management accounting.

* Study of (Altin, 2020), aims to measure the impact of the strategic management techniques used by industrial enterprises operating in the Ardum and Arzanan regional corporations. The study was made at 87 small and medium manufacturing companies in these two provinces, and the design of quantitative research was used in the study which was developed by (Jabarah, 2018) to collect data obtained through personal interviews with senior corporate executives. The study used a multi-linear regression analysis to test the assumptions and measurement of the model, while independent variables are components of strategic management accounting techniques (only in Production of time, balance capacity and cost targeting). The study concluded that the use of strategic management techniques through the manufacture of SMEs in Erzurum and Arzanan has a moderate effect on investment decisions in a complex and dynamic economic environment.

* A study of (Thapayom, 2019), aims to identify the relationships between (strategic management accounting techniques, organizational competitiveness, and sustainable organizational performance). Provided that organizational competitiveness is a mediator of study relations. The study was conducted on 148 companies in the industrial zones of Rayong. The study concluded: that the techniques of strategic management accounting, namely: strategic planning, control, performance measurement, accounting for competitors and accounting for customers, have a significant positive relationship with organizational competitiveness and sustainable organizational performance. Similarly, organizational competitiveness has an important positive relationship with sustainable organizational performance. To test the mediation effects of research relationships, organizational competitiveness is the mediator of strategic planning, control and performance measurement, organizational sustainable performance relationships, sustainable performance relationships between competitor accounting, and customer organizational sustainable performance relationships.

Accordingly, corporate executives need to develop, implement and improve strategic planning, control, performance measurement, competitor accounting, and customer accountability in order to create their organizational competitiveness and generate sustainable organizational performance by investing in appropriate valuable resources to support these aspects of technologies. The study recommended highlighting theoretical and managerial contributions, conclusions, suggestions and directions for future research.

* Study of (Ibrahim and Babiker: 2018), dealt with the role of strategic management accounting in supporting competitiveness, and aimed at clarifying the role of applying the continuous improvement method and the production method on time as one of the strategic management accounting methods in supporting competitiveness. The problem of the study was to show the effect of applying the continuous improvement method on competitiveness, and the effect of applying the production method on time on competitiveness. The study concluded that the continuous improvement method contributes to reducing costs to support competitiveness, and the on-time production method contributes to reducing the cost of un-invested capital in production inputs to support competitiveness.

* Study of (Rabiaa, 2018), aims to expose the strategic report as one of the reports required by the Financial Reporting Council in the United Kingdom. The study links the internal and external environment variables of the company to its strategy and business model. In addition to clarifying the company's sustainable and governance performance and its relationship to its strategy and determining the role of accounting. The strategic management in supporting the disclosure of the strategic report by addressing many issues represented in the principles on which the strategic report can be based on: the strategic management accounting tools that support the strategic report and the role of the management accountant in light of companies' disclosure of the strategic report, Study of (Ibrahim: 2016), aims to identify the methods of strategic management accounting and to provide a practical framework to highlight the role of strategic management accounting methods in reducing costs to achieve the objectives of the study. Strategic management has many characteristics that distinguish it from other traditional costing systems that have become unsuitable for the modern industrial environment. However, this may require some time for adequate understanding and training on the method of application, and the study recommended applying all the principles and foundations of these methods in order to take full advantage of them, and work to increase cooperation between all departments, sections and employees and raise their morale to achieve the planned goals effectively and successfully.

* Study of (Al-Ani: 2015), aims to study the impact of modern strategic management accounting techniques in improving the quality of financial reports for Jordanian companies for the human pharmaceutical industry. The study population and its sample consisted of all the Jordanian human pharmaceutical manufacturing companies listed in the records of the Jordanian Federation of Pharmaceutical Producers for the year (2014-2015), numbering (15) companies. As for the analysis unit, it consisted of financial managers and accountants working in Jordanian 
human pharmaceutical manufacturing companies that belong to the Jordanian Human Pharmaceutical Producers Union, numbering (137) individuals. To achieve the objectives of the study, the descriptive analytical method was used beside of each of the multiple regression analysis to test the hypotheses of the study. The study concluded that there is a statistically significant effect of the benchmarking technique in improving the quality of financial reports in the Jordanian companies for the human pharmaceutical industry. The presence of a statistically significant effect of the benchmarking technique in improving the quality of financial reports in terms of suitability and portability for understanding the Jordanian companies for the manufacture of human medicines.

* Study of (Al-Kashef: 2015), aims to shed light on client accounting as one of the strategic management accounting methods, knowing what they are and what are the factors motivating establishments to adopt them, what are the difficulties in implementing it?

A field study was conducted that included a sample of officials in some Saudi companies registered in the stock market. It became clear from the results of the study that six companies out of (14) companies have adopted one or more client accounting applications. Three companies were seeking to adopt them, while the rest of the companies did not implement any of them, as a result of the difficulties they face that limit their ability to implement them (information technology constraints, competing with other organizational priorities, and resistance to change, insufficient skills and weak advocacy for their adoption). The results of the study showed that the obstacles of adopting client accounting are closely related to the difficulties encountered in applying other innovative methods in strategic management accounting, such as activity-based costing and multi-measurement systems. That is why this study seek to fill the gap between the practical application of client accounting and what is generated by scientific research in this field. By providing more appropriate and robust evidence that supports the application of client accounting methods in practice and identifying potential obstacles when applied. The study recommended shedding light on some important considerations to be taken into account in future research in this field.

* A study of (Mohamed \& Jones: 2014), aims to propose a comprehensive strategic model for profitability management, through the adoption of the concepts of strategic management accounting. The study was from (467) companies working in the Egyptian telecommunications and technology sector. The analysis unit also included individuals working in those companies, including financial managers and executives. The deductive approach was used. After conducting statistical analysis, the study reached many results; most notably the proposed comprehensive profitability model that contains costing, asset and revenue techniques was a better predictor of profitability than alternative models, which contain a mix of the two variables.

* Study of (Arafa and Meligy, 2014), aims to test the extent of the relationship and impact of the company's strategy on the Strategic Management Accounting (SMA) system and its reflection on the company's performance and to test the relationship between business strategy (SMA). The study dealt with two dimensions: The first dimension is to identify the organizational formations that exist in the Egyptian business environment in the light of the similar characteristics of the study sample and according to the variables represented in the strategy and formulation, market orientation, study and strategic position, strategic management accounting methods, the extent of accountants' participation in strategic management, and testing the performance of these formations following the holistic approach. As for the second dimension is testing the correlation between (SMA) and business strategy according to the probabilistic approach. A sample of (148) financial managers in companies registered on the Egyptian Stock Exchange were surveyed to collect the data required to analyze the dimensions of the study. The results of the study showed that the practices of (SMA) were not affected in the Egyptian companies with the adopted business strategy. That did not reflect this on the company's performance, as the results of the study indicated to the Egyptian business environment used a large number of strategic management accounting methods, in addition to the variety of strategic choices used. The value chain method came at the forefront of these methods, followed by the customer profitability analysis method and the target cost method. The results of the study reflected an agreement between the total and probabilistic inputs.

* Study of (Abu Hamam: 2013), aims to identify the impact of Palestinian companies' use of strategic management accounting methods on the financing structure of these companies, by measuring the degree to which Palestinian companies practice strategic management accounting methods. A company listed on the Palestine Stock Exchange, and after conducting the necessary statistical analysis, the study concluded that there is an acceptable application by the Palestinian companies of management accounting methods, and this application ranges between $(31 \%)$ to $(61 \%)$. There is an inverse relationship with statistical significance between the Palestinian companies' practice of strategic management accounting methods and financing with property rights of those companies, as well as an inverse relationship with financing with retained earnings but it was not statistically significant. Furthermore, benefit from this effect, to reduce the risk of financing and thus its cost to a minimum.

* Study of (Al-Nawayseh: 2013), aims to know the extent to which strategic management accounting tools are applied in Jordanian banks, which include costs based on ABC activities, Benchmarking, Competitor Analysis, VC Customer Evaluation, Integrated Performance Measurement (IPM), Life Cycle Costs (LCC), Quality Costs 
QC and Control, The value of the brand BVM, management and budgeting MB, strategic pricing SP, target costing TC, value chain cost VCC and the balanced evaluation card; in addition to knowing whether there is an impact of the demographic characteristics of members responsible for these banks on realizing the importance of applying strategic management accounting tools. The study population consisted of Jordanian banks and included a sample of (30) individuals from the financial and administrative managers of Jordanian banks. After conducting statistical analysis, the study concluded that Jordanian banks do not use or apply strategic management accounting tools. The study recommended that Jordanian banks train their employees in the use of accounting tools.

* Study of (Ramljak \& Rogosic: 2012), aims to identify the importance of strategic management accounting techniques and their role in providing managers with information of relative importance in a timely manner. Also aimed to identify the role of these techniques represented by the cost system based on ABC activities and total quality management TQM in cost control and cost reduction. The study used the descriptive analytical approach through a survey list, which was distributed to (63) Croatian companies. After conducting statistical analysis, the study concluded that strategic management accounting information is useful for managers in supporting their decisions, through providing them with relevant information in a timely manner, as it works to control and reduce costs. The study also found that Croatian companies apply the techniques under study at very good levels.

* A study of (Akenbor \& Okoye: 2012), aims to determine the extent of the impact of strategic management accounting on the competitive advantage in industrial enterprises in Nigeria. The respondents' amounted to (300) indivisuals. The descriptive analytical approach was used through a questionnaire that was prepared to answer the questions of the study and test its hypotheses. After conducting statistical analyzes, the study reached many results, most notably that strategic management accounting enhances the competitive advantage in industrial enterprises in Nigeria.

* Study of (Fowzia: 2011), aims to show the level of use of strategic management accounting techniques and their relationship to the type of industry, the size of the industry, the strategic model, the strategic mission and the strategic position in the industrial organizations in Bangladesh, in addition to focusing on the impact of these techniques to achieve efficiency. The strategy of industrial organizations, the study was applied to 70 industrial organizations in Bangladesh that were chosen randomly. Strategic mission and strategic position, and the costing technique based on activities, target cost and strategic cost significantly affect the achievement of strategic efficiency.

* Study of (Sayyed: 2010), aims to study the role of the integration of strategic management accounting methods in strengthening the competitive advantage of the cement industry in Egypt. The steps of this model are considered as the leading step for the next step. The study also tested the extent to which the Egyptian environment applies a number of strategic management accounting methods, such as the balanced performance measure, customer profitability analysis, target costing, value chain, and benchmarking method (Benchmarking) in evaluating the performance of competitors. The study concluded that improving the overall performance of the enterprise and its global distinction depends on the integration of management accounting methods to implement the enterprise's strategy, control and evaluation of strategic performance.

* Study of (Al-Zumar: 2009), aims to show the extent of the impact of strategic management accounting methods on business environment variables and the extent of their application on organizational performance, by studying the relationship between the application of managerial accounting methods, and the extent to which measures of financial and non-financial performance are improved. In addition to studying the impact of the effectiveness of the competitive strategy adopted by the organization and the relationship between it and the strategic management accounting methods, the extent to which it supports the strategy of product excellence on the one hand, and the lowest cost on the other hand. The study recommends evaluating the methods of strategic management accounting in terms of the policies and objectives that the organization seeks to achieve and the extent of its ability to support competitive strategies in order to achieve the best position for the organizational performance of the organization.

* Study of (Al-Jalili, 2007), aims to present the concept of strategic accounting and how to contribute to achieving the objectives of economic units in light of new global developments and the extent of the concept's impact on the information provided by the accounting function, as well as examining the applied reality in the Iraqi environment. To activate the role of strategic management, the role of accounting must be changed to focus on a detailed understanding of the surrounding environment and problems to formulate and implement the strategies of the enterprise. The accounting department must work to provide detailed internal information, as well as cooperation with other departments in the enterprise to provide external information about competitors and attention to information useful in rationalizing strategic investment decisions and preparing investment budgets. What distinguishes the current study from previous studies?

The most important thing that distinguishes the current study from previous studies can be summarized as follows:

1. In terms of the study environment and the application sector: the previous studies were conducted on American and European organizations in addition to some Arab organizations such as commercial banks, while the current 
study will be applied to Palestinian industrial companies.

2. In terms of the aim of the study: the research trends of the previous studies varied, which aimed to assess the level of practice of strategic management accounting techniques in industrial and service institutions, in addition to identifying the quality of financial reports in the institutions under study, while the current study aimed to know the impact of strategic management accounting techniques. On the reliability of financial statements in Palestinian industrial companies.

\section{Theoretical framework of the study}

Strategic management accounting techniques

The concept, methods and characteristics of strategic management accounting

All researchers agreed to clarify the concept of strategic management accounting from two angles, namely, the methods of management accounting and the characteristics of management accounting (Langfield-Smith, 2008).

\section{- Strategic management accounting methods}

Cadez \& Guilding (2008) identified strategic management accounting methods with fifteen methods falling under five sections as follows:

1- Strategic cost, which includes: (characteristic cost, product life cycle cost, quality cost, target cost, and value chain cost).

2- Regulatory planning and strategic performance management, including: (Standards and integrated performance measurement)

3- Making strategic decisions, including: (strategic cost management, strategic pricing)

4- Customer Accounting, including: (customer profitability analysis, customer profitability analysis during the life cycle, customer assessment as assets).

As for Abul-Fadl (2016), he classified the tools and methods of strategic management accounting into five groups as follows:

1- Cost accounting methods, which are:

o Continuous improvement method (accounting for the costs of product or service quality)

o On-time production method (cost based on time-oriented activity)

o Activity-based cost accounting

o Cost accounting based on specifications

o Accounting for the lifetime costs of a product or service

o Accounting for value chain costs

o Accounting for target costs

2- Methods of accounting for competitors, which are:

o Competitors' cost assessment

o View the competitive position

o Evaluate the performance of competitors

3- Methods of monitoring and measuring performance, which are:

o Comparative or reference measurement

o Integrated performance measurement

\section{4- Accounting methods for clients, which are:}

o Customer profitability analysis

o Customer profitability analysis during the period of his dealings

o Evaluating the customer as one of the company's assets

\section{5- Strategic decision-making methods, which are: \\ o Strategic Pricing \\ o Brand evaluation}

\section{- Characteristics of strategic management accounting}

The external orientation refers to the importance of non-financial information about competitors, suppliers and customers; in addition to that, most management accounting methods are cost-based methods.

Arafa and Meligi (2015) defined modern management accounting as the modern concept that involves the importance of accountants' participation in strategic management and the use of modern administrative methods that would provide financial, non-financial, internal and external information (competitors, suppliers, customers) as an entry point to provide appropriate information and improve Efficiency and effectiveness of making decisions related to achieving the strategic objectives of the organization and improving performance and operations.

Al-Maryani and Sadik (2012) see that strategic management accounting is concerned with looking at information for the purpose of serving decision-makers, as strategic accounting is concerned with a number of elements such as (following the actions of competitors, studying the current strategic position, opportunities to obtain strategic 
advantages, strategic planning for the organization ).

Cinquini and Tenucci (2010) say that strategic management accounting reflects the conceptual content of management accounting that focuses on external aspects and thus focuses most of its attention on providing information related to the final product market and details of products, competitors and customers.

Ibrahim and Babkir (2018) defined it as a comprehensive method that aims to develop an integrated framework for providing and analyzing financial and non-financial data and information with the aim of using it to make and rationalize long-term decisions.

According to the above, the researchers see that strategic management accounting is a set of standards, tools and strategies that have been gradually developed from the traditional business environment to match the development of the modern economic business environment, which are considered as pillars on which competing companies rely in the open market to measure and evaluate their performance and maintain their continuity.

In the current study, the researchers will give an overview of modern strategic management accounting techniques:

\section{First: Techniques related to strategic costing, including: \\ - Product life cycle costs}

The length of the product life cycle affects the costs of the product, so controlling the length of the product life cycle increases or decreases the costs of the product. There is an inverse relationship between the length of the product life cycle and the costs of the product life cycle. The costs of the full life cycle of the product can be reduced by directing efforts towards the activities of the early stages of the life cycle and before the beginning of the production stage, and therefore the best approach is to analyze life cycle costs at the same time as the application of the target costing system (Kamal, 2013).

\section{- Target cost}

It is the cost that is built or determined on the basis of the market price of a particular product, then the profit margin to be achieved is determined from the price of this product, and the rest represents the target cost value, which should not exceed the production of this product (target cost $=$ competitive market price - target profit), and it is considered as the actual cost, and if the company manages to do that, it will produce the product with confidence, but if it finds that implementing the product will not achieve its goal because the expected cost exceeds the target cost, it will not produce it (Noor, 2015).

\section{- Estimation of quality costs}

It is the sum of the costs spent by the producer or originator for the purposes of determining and controlling the level of quality that the product reaches, and assessing the extent of conformity between the product specifications and the customer's desires, and it can also be defined as all costs incurred by the manufacturer to ensure that he produces a high-quality product, and quality costs include both among the costs to prevent low-quality production, the costs that arise after producing a low-quality product, and to measure quality costs, their type must be determined, which are (COQ 2019:

\section{1- The costs are of poor quality and are of two types:-}

A. Internal failure costs: They are represented in the costs of rework, scrap, retesting, disruption, failure analysis, process change, downgrading and loss of revenue.

B. The costs of external failure: They are represented in complaints, guarantees, repair of returns, exchanges, penalties, lost opportunities and the company's brand

\section{2- The costs are of good quality and are represented in:}

A. Prevention costs, including quality planning, operations planning, quality audits, and assessment of resource quality, education and training, and review of new products.

B. Product costs, including providing incoming goods and services, external inspection and inspection, field testing, system audits, standards for measuring and testing devices.

\section{- Value chain cost}

It is the series of activities that are relied upon to determine the value of the product and not its cost, and each product usually passes through several stages to reach the consumer in the required form, and these stages are expressed in the value chain, which starts from the stage of research and development, then to the stage of engineering and design, and then to the stage of manufacturing and its requirements and the final stage of finalization and others. Therefore, the product passes through all value chain activities in the work system in order, and in every step of the production process the value is doubled to the final product.

\section{Features costs}

The strategic cost management from the perspective of the entrance costs of attributes is the tool that operates from a sophisticated administrative and behavioral intellectual perspective in order to provide a product with distinctive characteristics, specifications and quality that satisfies the renewable consumer tastes at lower costs and competitive prices based on technical methods for cost and value analysis and linking activities and their performance levels. Characteristics is an entry point for measuring product costs, taking into account the 
characteristics and specifications of the product based on customer demand and market research, passing through the product design stage, and in light of the levels of achievement of each product specification. In addition, evaluating actual and planned costs with the same cost management methodology and measuring them in a way that is compatible with production methods in the modern manufacturing environment (Al-Zayni, 2019). Attribute costs are implemented by (Karout, 2017):

1. Studying the costs and benefits of each level of specifications, and this is done by determining the relative and less important specifications for a particular sector, and this leads to a reduction in cost without affecting the overall product benefit to the consumer, and this positively affects the volume of product sales.

2. In the case of product development and improvement, dividing the product into specific features and specifications helps in defining the features of each specification and determining which of them needs to be developed and whether it is possible to add new specifications to the product and what are the additional costs for that and what are the material returns to the company from this development and is it commensurate with the consumer.

3. Analyzing the product into its specifications distinguishes the negative and positive specifications, and accordingly, the overall benefit of the product to the consumer and the percentage of satisfaction is verified, and whether competitors pay attention to these specifications or not.

\section{Second: Techniques for supervisory planning and strategic performance management, including: - Benchmarking}

It is a terminology of strategic management and is a tool used to measure the performance of companies and benefit from experiences, whether successful or unsuccessful. It is also used to identify areas that need improvement and development and thus achieve distinction. Benchmarking aims to improve and develop performance and benefit from human resources and also aims to satisfy customers. In addition that is through the constant search to measure and compare the services and practices in a company with the best practices and services of other parties.

\section{- Integrated performance measurement}

The integrated performance system is defined as the information system that lies at the heart of the performance management process. The performance management process is a closed-loop control system that publishes policy and strategy and obtains feedback from various levels of business performance management (Ahmed, 2017).

\section{Third: Techniques for making strategic decisions, including: \\ - Strategic cost management}

Ahmed (2017) defined it as the management that is concerned with strengthening the competitive position of the organization in order to reach the best strategies that help achieve competitive advantages to ensure survival and continuity. It is concerned with achieving high competitive advantages in the short and long term after controlling the product life cycle in all its stages to reach it according to the specifications at the lowest possible cost with a focus on providing it with specifications that meet the needs of customers and reflect their competitive advantage.

\section{- Strategic Pricing}

It is the price set in order to control the costs and expenses of direct materials in terms of price and in terms of quantity:

- The price criterion for direct materials is the process through which the expected price is determined for one unit of the material in addition to all expenses related to shipping, fines and others. For example, if there is a price discount for these materials, the value of the discount is deducted from the final standard price.

- The criterion for the quantity of direct materials is the expected quantity of direct materials to be used to manufacture one unit of the final product, including the expenses and costs related to scrap.

\section{Fourth: Techniques for accounting for competitors, including: - Evaluate the cost of competitors}

Evaluating the cost of competitors is one of the foundations for accounting for competitors, through which the cost structure of competitors is determined. With the increase in competitive industrial capacity, knowledge of competitive strengths affects the level of cost and the strategic actions of decision makers, and knowledge of competitive strength at the cost level of the competitor leads to better performance for companies. The greatest success of leaders who realize their competitive advantage is through their ability to determine the cost of competitors, which helps them in the preferred cost position and determine the profit margin through which they can create continuous competition and achieve their integrated strategy. Based on the evaluation of the cost of competitors, the evaluation of the cost of competitors is a powerful tool to gain and maintain a competitive advantage in profit. Knowing the cost advantages and disadvantages of competitors enables the company to know the future behavior of competitors and the assessment of competitors' cost can affect investment, corporate behavior, production quantity and pricing policy. Therefore, the assessment of the cost of competitors greatly affects the net profit margin of manufacturing companies and also affects the equity of these companies (Ohaka, 2019). Here, researchers believe that public companies need actuarial experts for their ability to provide advice on evaluating the cost of competitors through the nature of their profession, which depends primarily on the 
orientalization of the future and predicting the outcome of the companies' business and through their knowledge and experience in the field, which helps them to accurately estimate the cost of competitors to the company. Assisting management in making the right decisions.

\section{- Evaluate the performance of competitors}

Evaluating the position of competitors in strategic management means identifying strengths and weaknesses, and this evaluation is considered a basis for identifying opportunities and threats.

Palestinian believes that assessing competitors' situation is an essential element of the company's strategy and that most companies do not conduct this type of assessment in a systematic and sufficient manner, as companies rely on informal impressions, guesses and intuition through information received by managers about competitors.

\section{- Monitoring the competitive position}

Institutions succeed or fail in managing their business under the influence of a group of active forces in their competitive environment, and that the organizational structure of the competitive environment for institutions operating in the same industry field determines the behavior of that institution in its competitive environment, and it is believed that the competitive behavior of any of these institutions produces a certain level of performance. On the long level, it leads to influencing the organizational structure from the factors that lead to the success or failure of the institution. The competitive position strategy is based on defining the regulatory environment for the competitive environment, defining the detailed rules of the game and showing the determinants that must be taken into account in choosing any of these institutions for their strategic practices within the industry in which it operates, and in order to maintain a good competitive position in the market of the institution, it must be fully aware of how these forces operate not only that, but the institution must know how to put itself in a position that gives it an appropriate competitive ability in the competitive capabilities of other institutions Competitive environment (Ben Saeed, Ahmed, 2012).

\section{Fifth: Techniques related to customer accounting, including: \\ - Customer profitability analysis}

Many modern administrative methods that focus on customers have appeared at the present time, such as managing the customer relationship, which is considered a database related to customers and maintaining it is useful for the purposes of studying the patterns and behavior of customers with whom the economic unit deals and working to meet the requirements and needs of customers with actual products and services. What is not included in these administrative methods and systems is the profitability of the customer, but rather it depends on the profitability of the products, as the economic units do not know the profitable customers and the unprofitable customers, so the economic unit must know the profitability of all customers to gain a competitive advantage in the competitive business environment (Turney, 2005).

The researchers believe that there are benefits to customer profitability analysis represented in maintaining customers by providing products and services to them efficiently and effectively to achieve a competitive advantage and gain customer satisfaction and transform unprofitable customers into profitable customers in terms of negotiating price and quality, and despite the benefits, there are also problems for profitability analysis The customer is concerned with avoiding going into detailed information about the cost and how to allocate it. It also requires time, effort and cost.

\section{- Analysis of customer profitability during the life cycle}

Customer profitability is defined as determining or allocating the company's returns and its costs according to customers in order to understand the profitability of each of the company's customers, and customer profitability is defined as the difference between the revenues collected from customers and the costs of each of the products and services provided to them. Customers, and analyze the costs that occurred due to these customers, and through it management can identify customers who have made significant contributions to the company's profits and customers who do not make profits and accordingly they must obtain a level of interest from the company equivalent to their contribution to the company's profitability. The customer profitability analysis approach depends on the actual data related to a specific customer or group of customers to reach their profitability. It does not provide predictive information about the profitability of customers in the future (Assaad, 2014).

\section{- Evaluate customers as assets}

Institutions seek to evaluate their customers through their products, and this is done through the benefit that accrues to the customer as a result of his purchase of the product. The value of the customer is determined by three main factors: quality, service, and price. This reduces the demand for the product whose value decreases and its price increases. Therefore, the value of the customer can be measured in two ways:

Desired value: It is what the customer expects from the product without continuing to buy it - Perceived value: It considers that cost plays an important role in determining the value of the customer because it is the separator between the customer's choices for the product through similar competitors (www.meemapps.com).

\section{- Brand Accounting/Evaluation}

Brand valuation can be defined as the process used to calculate the value of a brand or the amount of money 
another party is willing to pay for it or the financial value of a brand. Although the concept of brand value is structured similarly to the concept of brand equity, it is distinct. Since property rights are dealt with from the consumer's perspective, brand value deals more with the company's perspective, Srivastava and Shocker (1991) defined brand ownership as a multidimensional structure consisting of brand strength and brand value, meaning that brand ownership is much broader than Brand value (Sakshi Sharma, 2017)

\section{- Environmental management accounting}

The environmental cost of any facility is the sacrifice that society bears in the form of the resources consumed by the facility as a result of its activity. Therefore, the main objective of environmental accounting is to disclose the company's obligations for the damage it causes to the environment by measuring the impact of pollution and determining the size and nature of the unit's contribution to environmental projects. And the extent of their impact on noise, congestion, consumption, and available services.

Environmental management accounting is a type of environmental accounting, through which the focus is placed on the balances of matter and energy and environmental cost information, and is divided into (Aamer, 2019):

Partial Environmental Accounting: It is an accounting tool concerned with defining an investment activity or a project concerned with preserving the environment through operations, as well as the environmental effects for a specific period.

Environmental Accounting for Environmental Balance: It is an accounting tool used to identify sustainable environmental management activities.

Environmental accounting for companies: It is an accounting tool used to issue environmental reports for a company to help users of financial statements and inform them of information related to sustainable development activities and environmental accounting.

The practical framework of the study (field study): This aspect dealt with the following procedures:

\section{First: Study Methodology:}

The study relied on the use of the descriptive analytical approach in order to reach logical results, and support the hypotheses in the research, and secondary sources were used, which include literature that dealt with the subject as well as what has been published of research, scientific letters and specialized periodicals related to the topic of research, and the researchers also resorted to collecting primary data to address the analytical aspects of the research subject through the questionnaire as a main tool for research, it was designed specifically for this purpose. The SPSS statistical program was also used to analyze the questionnaire (data), and to test the research hypotheses.

Second: The study population: The research community consists of workers in joint-stock industrial companies, whose number is (110) employees, and the comprehensive inventory method was used for the small size of the community, where (110) questionnaires were distributed to the research community, and (90) questionnaires were retrieved with a recovery rate $(81 \%)$ approximately.

Third: The study tool: The questionnaire was divided into two parts as follows:

* The first section: consists of the demographic data of the research sample, and it consists of (3) paragraphs.

* Section Two: It was divided into two axes as follows:

- The first axis: Determining the extent to which strategic management accounting techniques are practiced in industrial companies listed on the Palestine Exchange, and it consists of (8) paragraphs.

- The second axis: the orientations of specialists in industrial companies about the impact of using strategic management accounting techniques, and it consists of (8) paragraphs.

The answers to the axes' paragraphs were according to the five-point Likert scale, as shown in Table 1:

Table 1: Likert scale scores

\begin{tabular}{|c|c|c|c|c|c|}
\hline Classification & $\begin{array}{c}\text { Very } \\
\text { large }\end{array}$ & Large & Medium & Few & Very few \\
\hline $\begin{array}{c}\text { Degree of } \\
\text { approval }\end{array}$ & 5 & 4 & 3 & 2 & 1 \\
\hline
\end{tabular}

Fourth: The validity of the questionnaire: The validity of the questionnaire means making sure that it measures what it was prepared to measure, and honesty means "the inclusion of the questionnaire for all the elements that must be included in the analysis on the one hand, and the clarity of its paragraphs and vocabulary on the other hand, so that it is understandable to everyone who uses it.

The researchers verified the validity of the questionnaire in two ways:

1- Apparent honesty: where the questionnaire was presented to a group of arbitrators, which consisted of a number of faculty members in Palestinian universities and colleges in the Gaza Strip and specialists in 
accounting and statistics. Resolution in its final form.

2- Structural validity: The structural validity of the questionnaire items was calculated on the study sample, and it shows the extent to which each field of research is related to the total score of the questionnaire items, by calculating the correlation coefficient between the total score for each axis and the total score for the questionnaire. Table 2 shows that all coefficients of correlation in all axes of the questionnaire at the level of significance (0.05). Where the probability value is less than 0.05 ).

Table 2: Correlation coefficient between the total score for each axis and the total score for the questionnaire

\begin{tabular}{|l|l|l|l|}
\hline \multicolumn{1}{|c|}{$\begin{array}{c}\text { Axis } \\
\text { number }\end{array}$} & \multicolumn{1}{|c|}{ Correlation coefficient } & Prob. & $\begin{array}{c}\text { Sig. } \\
\text { value }\end{array}$ \\
\hline 1 & $\begin{array}{l}\text { Determining the extent to which strategic management } \\
\text { accounting techniques are practiced in industrial companies } \\
\text { listed on the Palestine Exchange. }\end{array}$ & 0.853 & 0.000 \\
\hline 2 & $\begin{array}{l}\text { Attitudes of specialists in industrial companies about the } \\
\text { impact of using strategic management accounting } \\
\text { techniques. }\end{array}$ & 0.877 & 0.000 \\
\hline \multicolumn{1}{|c|}{ All axles together } & 0.865 & 0.000 \\
\hline
\end{tabular}

Fifth: The stability of the resolution: The stability of the resolution means making sure that the answer will be almost the same if it is repeated on the same people at another time.

Table 3: Cronbach's alpha coefficients to measure the stability of the resolution

\begin{tabular}{|c|c|c|c|c|}
\hline S. & The Axis & $\begin{array}{l}\text { Number of } \\
\text { paragraphs }\end{array}$ & $\begin{array}{r}\text { Coefficient of } \\
\text { (Cronbach's } \\
\text { alpha) }\end{array}$ & $\begin{array}{r}\text { Honesty } \\
\text { coefficient }\end{array}$ \\
\hline 1 & $\begin{array}{l}\text { Determining the extent to which strategic management } \\
\text { accounting techniques are practiced in industrial } \\
\text { companies listed on the Palestine Exchange. }\end{array}$ & 16 & 0.932 & 0.937 \\
\hline 2 & $\begin{array}{l}\text { Attitudes of specialiats in induatrial companies about } \\
\text { the impact of using strategic management accounting } \\
\text { techniques. }\end{array}$ & 8 & 0.910 & 0.926 \\
\hline & All axes together & 24 & 0.921 & 0.932 \\
\hline
\end{tabular}

The results shown in Table 3 show that the validity coefficient (Cronbach's alpha) ranged between $0.910-0.932$, which is a high stability coefficient, which indicates that the It makes it valid to answer the study's questions and test its hypotheses.

\section{Sixth: Data analysis and testing:}

1- Normal distribution test (Kolmgrove-Smirnov test):

The researchers used the Colmgrove-Smirnov test to see if the data followed a normal distribution. It is a necessary test in the case of hypotheses testing, because most laboratory tests require that the data distribution be normal, and Table 4 shows that the calculated T-test value is greater than the tabular $\mathrm{T}$ value, as well as the significance level greater than 0.05 (sig. > 0.05) and this indicates that the data follow a normal distribution, and parametric tests should be used.

Table 4 Normal distribution test (1 - Sample Kolmogorov - Smirnove)

\begin{tabular}{|c|c|c|c|c|}
\hline Axis & Axis title & $\begin{array}{c}\text { Number } \\
\text { Paragraphs }\end{array}$ & $\begin{array}{c}\text { Value } \\
\mathrm{T}\end{array}$ & Prob. value \\
\hline The first & $\begin{array}{c}\text { Determining the extent to which strategic } \\
\text { management accounting techniques are practiced in } \\
\text { industrial companies } \\
\text { listed on the Palestine Exchange. }\end{array}$ & 16 & 0.624 & 0.397 \\
\hline $\begin{array}{c}\text { The } \\
\text { second }\end{array}$ & $\begin{array}{c}\text { Attitudes of specialists in industrial companies about } \\
\text { the impact of using strategic management accounting } \\
\text { techniques. }\end{array}$ & 8 & 0.677 & 0.368 \\
\hline
\end{tabular}

2- Statistical tools used in the study: The following statistical tools were used:

- Percentages, frequencies, and arithmetic mean: This command is mainly used for the purposes of knowing the frequency of the categories of a variable and is used in describing the study sample.

- Cronbach's Alpha test, to determine the stability of the resolution items.

- Using the Kolmogorov-Smirnov Test This test is used to find out whether the data follow a normal distribution or not. 
- Pearson's Correlation Coefficient (Spear man Correlation Coefficient) to measure the degree of correlation: This test is based on studying the relationship between two variables. It was used to calculate the internal consistency, the structural validity of the questionnaire, and the relationship between the variables.

- Test (one-sample t-test, not sign) in the case of one sample to see if the average response degree has reached neutrality, which is 6 , increased or decreased than that. It was used to ensure the significance of the average for each paragraph of the questionnaire.

\section{Seventh: Characteristics and characteristics of the study community:}

Table 5 Personal data of the sample

\begin{tabular}{|c|c|c|c|c|}
\hline Data & Item & Number & Percentage & Frequency \\
\hline \multirow{3}{*}{ Qualification } & Bachelor's & 75 & 83.4 & 1 \\
\hline & Master's & 12 & 13.3 & 2 \\
\hline & $\mathrm{PhD}$ & 3 & 3.3 & 3 \\
\hline \multicolumn{2}{|l|}{ Total } & \multicolumn{2}{|r|}{90} & $\% 100$ \\
\hline \multirow{4}{*}{ Job title } & Financial Manager & 17 & 18.9 & 3 \\
\hline & Head of Finance & 20 & 22.2 & 2 \\
\hline & Accountant & 11 & 12.2 & 4 \\
\hline & Other & 5 & 5.6 & 5 \\
\hline \multicolumn{2}{|l|}{ Total } & & \multicolumn{2}{|c|}{$\% 100$} \\
\hline \multirow{4}{*}{$\begin{array}{c}\text { Years of } \\
\text { Experience }\end{array}$} & less than 5 years & 15 & 16.7 & 4 \\
\hline & 6-10 years old & 20 & 22.2 & 2 \\
\hline & 11-15 years old & 30 & 33.3 & 1 \\
\hline & more than 15 years & 25 & 27.8 & 3 \\
\hline \multicolumn{2}{|l|}{ Total } & \multicolumn{3}{|c|}{$\% 100$} \\
\hline
\end{tabular}

It is clear from Table 5 that (83.4\%) of the study sample hold a bachelor's degree, (13.3\%) hold a master's degree, and $(3.3 \%)$ hold a doctorate degree, and this can be explained that a not simple percentage of these are from Holders of university degrees and most of them (bachelor's).

A percentage of $(41.1 \%)$ of the study sample worked as the owner or partner of the audit office, while (22.2\%) worked as a chief auditor, and (18.9\%) worked as an audit manager, and (12.2\%) worked as an assistant auditor, and the percentage of $(5.6 \%)$ are working other, and this can be explained that most of the study sample are onthe-job auditors.

A percentage of $(33.3 \%)$ of the study sample had a duration of work experience from 11-15 years, while $(27.8 \%)$ had a work experience of more than 15 years, and (22.2\%) had a work experience of $6-610$ years, and (16.7\%) less than 5 years, and this can be explained by the fact that most of the study sample have great experience in the field of auditing.

\section{Eighth: Testing the study's hypotheses:}

1- The first hypothesis: Palestinian industrial companies do not practice strategic management accounting techniques at a relative weight of $60 \%$ or less.

To test the first hypothesis, the researchers used a one-sample T-test for all the paragraphs of the first axis and the total score for its paragraphs. Table 6 presents the results: 
Table 6: The results of the single-sample T-test for all paragraphs of the first axis and the total score for its Paragraphs

\begin{tabular}{|c|c|c|c|c|c|c|c|}
\hline No & Paragraphs of the first axis & $\begin{array}{c}\text { Aritbmetic } \\
\text { mean }\end{array}$ & $\begin{array}{l}\text { Standard } \\
\text { deriation }\end{array}$ & $\begin{array}{c}\text { Relative } \\
\text { weight }\end{array}$ & $\begin{array}{l}\text { Test } \\
\text { value } \\
\text { (T) }\end{array}$ & $\begin{array}{l}\text { Value } \\
\text { (Sig.) }\end{array}$ & Rank \\
\hline 1 & $\begin{array}{l}\text { Evaluating the cost of competitors } \\
\text { leads to enhanced strategic decision- } \\
\text { making of the organization. }\end{array}$ & 4.41 & 88.2 & 0.426 & 23.644 & 0.000 & 6 \\
\hline 2 & $\begin{array}{l}\text { Evaluating the performance of } \\
\text { competitors: where the facility must } \\
\text { have a performance evaluztion system, } \\
\text { and its development to measure the } \\
\text { performance of competitors. }\end{array}$ & 4.35 & 87.0 & 0.472 & 20.169 & 0.000 & 12 \\
\hline 3 & $\begin{array}{l}\text { Customer Profitability Analysis: A } \\
\text { technique that tracks a customer's costs } \\
\text { and sales, and determines its annual } \\
\text { profit. }\end{array}$ & 4.45 & 89.0 & 0.364 & 28.878 & 0.000 & 3 \\
\hline 4 & $\begin{array}{l}\text { Lifetime Customer Profitability } \\
\text { Analysis: This tecknique goes beyond } \\
\text { calculating the annual profit, and looks } \\
\text { at the expected future profits that will } \\
\text { result from a business relationship with } \\
\text { a particular customer, as the customer's } \\
\text { profitability changes with the length of } \\
\text { the business relationship. }\end{array}$ & 4.39 & 87.8 & 0.428 & 23.060 & 0.000 & 8 \\
\hline 5 & $\begin{array}{l}\text { Integrated performance measurement: } \\
\text { through the application of the balanced } \\
\text { scorecard, through the availability of } \\
\text { financial and non-financial } \\
\text { performance measures. }\end{array}$ & 4.34 & 86.0 & 0.788 & 19.677 & 0.000 & 13 \\
\hline 6 & $\begin{array}{l}\text { Estimating life cycle costs: It means } \\
\text { classifying costs according to the } \\
\text { stages that include the life of the } \\
\text { product, and they are useful to } \\
\text { management in short-term deciaions. }\end{array}$ & 4.48 & 89.6 & 0.324 & 33.388 & 0.000 & 2 \\
\hline$?$ & $\begin{array}{l}\text { Estimating quality costs: It is done by } \\
\text { categorizing quality costs into } \\
\text { (prevention costs, evaluation, internal } \\
\text { failure and external failure), as this } \\
\text { tecknique helps in estimating lost sales } \\
\text { costs as a result of poor quality. }\end{array}$ & 4.36 & 87.2 & 0.404 & 23.838 & 0.000 & 10 \\
\hline 8 & $\begin{array}{l}\text { Strategic cost management: It is } \\
\text { carried out through the method of } \\
\text { value chain analysis, and attention is } \\
\text { paid to marketing by locating the } \\
\text { product as the most important in } \\
\text { making strategic decisions. }\end{array}$ & 4.30 & 86.0 & 0.419 & 21.564 & 0.000 & 14 \\
\hline 9 & $\begin{array}{l}\text { Standard (strategic) price policy: It is } \\
\text { widely used in pricing decisions, as it } \\
\text { is based on historical data that needs a } \\
\text { process of analysis and study to } \\
\text { estimate the standard price. }\end{array}$ & 4.40 & 88.8 & 0.428 & 23.060 & 0.000 & $?$ \\
\hline 10 & $\begin{array}{l}\text { Benchmarking: It means comparing } \\
\text { the actual performance with the } \\
\text { planned benchmark, and this applies to } \\
\text { the pricing policy taken (actual and } \\
\text { benchmark). with the aim of } \\
\text { improving the organizational practices } \\
\text { of companies. }\end{array}$ & 4.39 & 87.8 & 0.375 & 26.276 & 0.000 & 8 \\
\hline 11 & $\begin{array}{l}\text { Target cost: Determining the target } \\
\text { price that will provide the desired } \\
\text { market share, and then determining the } \\
\text { target cost to provide the desired } \\
\text { product profit, a technique based on } \\
\text { reducing costs when developing a } \\
\text { specific product or designing a new } \\
\text { product. }\end{array}$ & 4.38 & 89.2 & 0.422 & .23275 & 0.000 & 11 \\
\hline 12 & $\begin{array}{l}\text { Evaluating customers as assets: the } \\
\text { basis of profits is produced through the } \\
\text { relationship with the customer, and } \\
\text { this falls under the heading of humen } \\
\text { resources accounting. which the }\end{array}$ & 4.42 & 88.4 & 0.414 & 24.724 & 0.000 & 5 \\
\hline & $\begin{array}{l}\text { Westem world began to apply to a } \\
\text { large extent. }\end{array}$ & & & & & & \\
\hline 13 & $\begin{array}{l}\text { Value Chain Costing: This technique } \\
\text { focuses on factors outside the firm, } \\
\text { looking for all activities that create } \\
\text { value and are associated with the } \\
\text { product, such as the facility's linkages } \\
\text { with suppliers. }\end{array}$ & 4.33 & 86.6 & 0.453 & 20.512 & 0.000 & 4 \\
\hline 14 & $\begin{array}{l}\text { Features costs: a development of the } \\
\text { activity-based cost accounting system, } \\
\text { as it combines strategic cost } \\
\text { management with the aim of reducing } \\
\text { it while maintaining quality and } \\
\text { customer satisfaction, accurate and } \\
\text { objective meastrement of production } \\
\text { costs, and evaluating actual and } \\
\text { planned costs with the same cost } \\
\text { management methodology, and } \\
\text { measuring them in a manner consistent } \\
\text { with the methods Production in a } \\
\text { modern manufacturing environment. }\end{array}$ & 4.41 & 88.2 & 0.515 & 19.688 & 0.000 & 6 \\
\hline 15 & $\begin{array}{l}\text { Brand management accounting: It is a } \\
\text { technique based on linking accounting } \\
\text { information to improving brand and } \\
\text { customer loyalty. }\end{array}$ & 4.77 & 95.4 & 0.489 & 27.994 & 0.000 & 1 \\
\hline 16 & $\begin{array}{l}\text { Environmental management } \\
\text { accounting: It is concerned with } \\
\text { collecting, determining and estimating } \\
\text { envirommental costs, and amalyzing } \\
\text { information in order to make better } \\
\text { decisions within the organization. }\end{array}$ & 4.41 & 89.0 & 0.646 & 15.732 & 0.000 & 9 \\
\hline \multicolumn{2}{|r|}{$\begin{array}{l}\text { Determining the extent to which strategic } \\
\text { management accounting techniques are } \\
\text { practiced in Palestinian industrial } \\
\text { companies }\end{array}$} & 4.33 & 86.6 & 0.739 & 12.579 & 0.000 & $\cdot$ \\
\hline
\end{tabular}


*The correlation is statistically significant at the significance level $\alpha \leq 0.05$.

It is clear from Table 6 that Paragraph No. 15 states "Brand Management Accounting, a technique based on linking accounting information to improving brand and customer loyalty." It obtained the highest arithmetic average of (77.4) and the relative weight (95.4\%), while paragraph (8) which states "Strategic cost management: is done through the method of value chain analysis, and attention is paid to marketing by locating the product as the most importance in making strategic decisions. I got the lowest arithmetic average (4.30) and the relative weight $(86.00 \%)$.

In general, the arithmetic mean of collecting the first hypothesis paragraphs equals (4.33) and the relative weight equals $(86.6 \%)$, which is greater than the neutral relative weight $(60 \%)$, which indicates that the Palestinian industrial companies practice strategic management accounting techniques

Based on the previous results, the alternative hypothesis was accepted, and the null hypothesis was rejected, which states that "Palestinian industrial companies do not practice strategic management accounting techniques."

The researchers believe that the approval of the sample members to a large extent that Palestinian industrial companies practice strategic management accounting techniques, this indicates that industrial companies in the Gaza Strip pay attention to strategic management accounting techniques and use them in the manufacturing process, and the results of the study agreed with the study (ALTARAWNEH, 2021), which She stressed that the commitment of Jordanian industrial companies to strategic management accounting techniques is high, and the results of the current study agreed with the study (Ibrahim and Babiker, 2018), which showed that strategic management accounting methods reduce costs and support competitiveness, and also agreed with the study (Ibrahim, 2016). Which concluded that the use of strategic management accounting methods is characterized by its continuous interaction with the external environment to know the desires of the work and achieve them in the form of products that satisfy the customer's desire and at the same time reduce costs, and it is consistent with the study (Al Kashef, 2015), which shed light on the importance of accounting the client as a type of accounting techniques Strategic management, and also agreed with the study (Ramljak \& Rogosic: 2012), which concluded that evil Croatian Cat applies the techniques under study to very good levels.

2- The second hypothesis: Strategic management accounting techniques do not play any role or impact according to the viewpoint of specialists in industrial companies at a relative weight of $60 \%$ or less.

To test the second hypothesis, the researchers used a one-sample T-test for all the paragraphs of the second axis and the total score for its paragraphs. Table 7 presents the results:

Table 7: T-test results for one sample for all paragraphs of the second axis and the total score for its paragraphs

\begin{tabular}{|c|l|c|c|c|c|c|c|}
\hline $\mathbf{N o}$ & \multicolumn{1}{|c|}{ Paragraphs of the first axis } & $\begin{array}{c}\text { Arithmetic } \\
\text { mean }\end{array}$ & $\begin{array}{c}\text { Standard } \\
\text { deviation }\end{array}$ & $\begin{array}{c}\text { Relative } \\
\text { weight }\end{array}$ & $\begin{array}{c}\text { Test } \\
\text { value } \\
\text { (T) }\end{array}$ & $\begin{array}{c}\text { Value } \\
\text { (Sig.) }\end{array}$ & Rank \\
\hline $\mathbf{1}$ & $\begin{array}{l}\text { Facilitate the investment } \\
\text { decision-making process. }\end{array}$ & 4.61 & 0.584 & 92.2 & 20.711 & 0.000 & 2 \\
\hline $\mathbf{2}$ & $\begin{array}{l}\text { Accelerate the investment } \\
\text { decision-making process. }\end{array}$ & 4.14 & 0.586 & 82.8 & 12.620 & 0.000 & 8 \\
\hline $\mathbf{3}$ & $\begin{array}{l}\text { Providing highly qualified } \\
\text { professionals to deal with } \\
\text { management accounting } \\
\text { methods in making investment } \\
\text { decisions. }\end{array}$ & 4.71 & 0.640 & 94.2 & 20.459 & 0.000 & 1 \\
\hline $\mathbf{4}$ & $\begin{array}{l}\text { Analyze aspects of an } \\
\text { investment decision. }\end{array}$ & 4.31 & 0.662 & 86.2 & 13.746 & 0.000 & 5 \\
\hline $\mathbf{5}$ & $\begin{array}{l}\text { Make investment decisions } \\
\text { related to solving a particular } \\
\text { problem. }\end{array}$ & 4.35 & 0.757 & 87.0 & 12.548 & 0.000 & 4 \\
\hline $\mathbf{6}$ & $\begin{array}{l}\text { Ability to identify quantitative } \\
\text { and non-quantitative } \\
\text { information in various fields. }\end{array}$ & 4.42 & 0.414 & 88.4 & 24.724 & 0.000 & 3 \\
\hline $\mathbf{7}$ & $\begin{array}{l}\text { The ability to manage economic, } \\
\text { environmental and social costs. }\end{array}$ & 4.26 & 0.676 & 85.2 & 12.722 & 0.000 & 6 \\
\hline $\mathbf{8}$ & $\begin{array}{l}\text { Improving the performance of } \\
\text { industrial companies by } \\
\text { satisfying customers and } \\
\text { developing new products. }\end{array}$ & 4.17 & 0.652 & 83.4 & 11.806 & 0.000 & 7 \\
\hline $\begin{array}{l}\text { Attitudes of specialists in industrial } \\
\mathbf{6} \\
\mathbf{u s m} \\
\mathbf{a c c o u n g} \text { strategic management }\end{array}$ & 4.36 & 0.415 & 87.2 & 23.075 & 0.000 & - \\
\hline
\end{tabular}

*The correlation is statistically significant at the significance level $\alpha \leq 0.05$. 
It is clear from Table 7 that Paragraph (3) provides for "providing highly qualified professionals to deal with administrative accounting methods in making investment decisions." It obtained the highest arithmetic average of (4.71) and the relative weight $(94.2 \%)$, while paragraph (2) which states "accelerate the investment decisionmaking process". She obtained the lowest mean of (4.14) and the relative weight $(82.8 \%)$.

In general, the arithmetic mean of collecting the paragraphs of the second hypothesis equals (4.36) and the relative weight equals (87.2) which is greater than the neutral relative weight $(60 \%)$, which indicates that strategic management accounting techniques play any role or impact according to the viewpoint of specialists in industrial companies. Palestinian contribution.

Based on the previous results, the alternative hypothesis was accepted, and the null hypothesis was rejected, which states that "strategic management accounting techniques do not play any role or impact according to the viewpoint of specialists in industrial companies."

The researchers believe that the agreement of the sample members to a large extent that strategic management accounting techniques play an important role according to the viewpoint of specialists in industrial companies, this indicates that Palestinian industrial companies attach great importance to the use of modern techniques of strategic management accounting in order to make sound decisions related to production and marketing operations and selling, as well as decisions related to reducing production costs and other decisions. The results of the study agreed with the study (ALTARAWNEH, 2021), which confirmed that the level of competitive advantage dimensions is high for Jordanian industrial companies that use strategic management accounting techniques, and also agreed with the study (ALTIN, 2020), which confirmed that strategic management accounting techniques have a moderate impact on decisions The investment of small and medium- sized industrial companies, as well as agreed with the results of the study (THAPAYOM, 2019), which emphasized the impact of strategic management accounting techniques on organizational competitiveness and organizational performance of medium and small industrial companies,

The results of the current study also agreed with the study (Syed, 2010), which concluded that improving the overall performance of the facility and its global distinction depends on the integration of management accounting methods to implement the facility's strategy, control and evaluation of strategic performance, and it is consistent with the results of the study (Spring, 2018), which found the importance of Strategic management accounting tools and information that the management accountant can provide in explaining and interpreting the information within the strategic report, also agreed with the study (Ramljak \& Rogosic: 2012), which concluded that strategic management accounting information is useful for managers in supporting their decisions, by providing them with relevant information. In time, it also works on commissioning oversight and downgrading.

\section{Findings and Recommendations:}

\section{First: Results: Based on the statistical analysis, the researchers reached the following results:}

- The industrial companies operating in the Gaza Strip pay attention to the techniques of strategic management accounting and use them in various manufacturing processes, but it still requires further promotion and guidance.

- Strategic management accounting techniques play an important role according to the viewpoint of specialists in Palestinian industrial joint-stock companies, as they attach great importance to the use of modern management accounting techniques in order to make sound decisions related to production, marketing and sales operations, as well as decisions related to reducing production costs and other decisions.

- Providing highly qualified professionals in the Palestinian industrial joint stock companies to deal with the methods of managerial accounting.

- The Palestinian joint stock industrial companies classify costs according to the stages that include the life of the product, and they are useful to the managements of these companies, who use them in making short-term decisions.

- The Palestinian industrial joint stock companies are developing the activity-based cost accounting system, as it combines strategic cost management with the aim of reducing it while maintaining quality and customer satisfaction, accurate and objective measurement of production costs, and evaluating actual and planned costs with the same cost management methodology and their measurement in harmony with production methods in the modern manufacturing environment.

- There are tendencies for specialists in Palestinian industrial joint stock companies to use strategic management accounting techniques to facilitate and speed up the investment decision-making process, identify quantitative and non-quantitative information in various fields, and manage economic, environmental and social costs.

- The information provided by strategic management accounting helps to support disclosure in general, and financial reports in particular, as it is required to use strategic management accounting tools that support those reports such as internal and external environment assessment tools, strategic management support tools, business model support tools, and related tools. Supporting the performance of Palestinian industrial joint stock companies.

- Strategic management accounting worked to move from operational issues to focus on issues of strategic orientation through the integration of operations for financial and human resources, which made the management accountant an essential role in the strategic decision-making process of Palestinian industrial joint-stock companies.

- There are reasons that may limit the application of modern administrative accounting methods, which are the 
lack of conviction of the currently applied methods, the high cost of application, poor knowledge of these methods, lack of awareness of the importance of modern methods, the lack of conviction of the senior management of their importance, the failure of accountants to obtain sufficient training courses, and the lack of knowledge by modern methods.

\section{Second: Recommendations: Based on the previous results, the researchers recommend the following:}

- The necessity for companies to use modern methods of managerial accounting in the field of planning, control and performance evaluation, which leads to the invention of new measurement methods related to customer satisfaction and its maintenance and the satisfaction of employees and the development of their skills as basic factors for evaluating how these companies work.

- Working on developing management accounting methods to match its philosophy and objectives with the modern requirements of the industrial renaissance, the environment and the economic environment to enable Palestinian industrial companies to compete and maintain continuity.

- Work to increase the awareness of officials in Palestinian industrial joint-stock companies of the importance of applying modern management accounting methods to provide appropriate information that helps managers to carry out their functions such as planning, control, performance evaluation and decision-making.

- Conducting more studies and research on advanced methods and modern systems for strategic management accounting, and trying to link them to general accounting systems.

- The necessity of linking the modern strategic management accounting techniques with the various accounting systems in order to achieve efficiency and effectiveness in managing costs in the Palestinian industrial joint stock companies.

- Develop a training program for workers in Palestinian industrial joint stock companies for training on how to apply and use strategic management accounting techniques that provide oversight and performance evaluation in order to compete and survive in an environment characterized by complexity and uncertainty.

- The necessity for universities, research centers and a professor of modern management accounting to double their interests in writing scientific research that sheds light on modern management accounting.

- The necessity for professional associations to hold seminars, workshops and conferences on modern management accounting methods in order to confront the rapid changes in the economic environment and achieve competitive advantage in light of the challenges of globalization.

\section{References}

[1]. Ibrahim, Fadlallah Barir Jaafar and Babiker, Bashir Bakri Ajeeb (2018): The Role of Strategic Management Accounting Tools in Supporting Competitiveness, Delta Journal of Science and Technology, Issue Seven, March,

[2]. Ibrahim Muhammad Mamoun Tamim Al-Dar (2016): "Methods of strategic management accounting and their role in supporting competitive advantage", unpublished master's thesis.

[3]. Abu Al-Fadl, Abdel-Aal mustafa (2016): "Measuring the extent to which strategic management accounting tools (methods) are applied and workers' awareness of the importance of their application in Saudi banks", Journal of Accounting Thought, Ain Shams University, Faculty of Commerce, Vol. 20, No. 1, Egypt.

[4]. Abu Al-Fadl, Abdel-Aal mustafa (2016): "Measuring the extent to application of strategic management accounting tools (methods) and workers' awareness of the importance of their application in Saudi banks, Journal Of Accounting Thought, Volume 20, Issue 1, Faculty of Commerce, Ain Shams University, Cairo.

[5]. Abu Haman, Hassan Issa (2013): "Strategic management accounting methods applied by companies listed on the stock exchange and their impact on the financing structure of those companies", Ain Shams University, Faculty Of Commerce, Journal of Accounting Fikr, No. 3.

[6]. Ahmed, Mohammad Osman Ibrahim (2017) "Strategic cost management and its role in cost control and administrative decision- making" A field study on Sudanese industrial companies, PhD thesis, College of Business Studies, Sudan University of Science and Technology.

[7]. Asaad, Basil, (2014), The Role of the Costumer Profitability Analysis Entrance in Rationalizing Administrative Decision, Damascus University Journal of Economic and legal Science, Volume 30Second Issue, Faculty of Economic, Damasus University.

[8]. Ben Said, Amin and Ahmed, Zughdar, (2012), The Role of Cost Management from a Strategic Perspective in Enhancing the Competitive Position, Journal of Economic and Financial Studies, Sixth Issue- Volume One, Valley University, Algeria.

[9]. Al-Jalili, Miqdad Ahmed Yahya (2007): “The Conceptual Framework for Strategic Accounting and its Applications in the Iraqi Environment", Al-Rafidain Development Journal, 86 (29), pp. 9-27, Iraq.

[10]. Daiya, Hadi Mohsen (1994): "Strategic Management Accounting, the Accounting Approach in Competition Marketers", Benha University, Faculty of Commerce, Journal of Commercial Studies and Research, No. 2, Egypt.

[11]. Rabie, Marwa Ibrahim, (2018) "The Future of narrative reform from the perspective of strategic management accounting with an exploratory study", the first scientific conference of the Department of Accounting and Auditing "The Role of Accounting and Auditing in Supporting Economic and Social 
Development in Egypt - during the period from 6-7, May 2017, Faculty of Commerce, Alexandria University, Egypt.

[12]. Al-Zumar, Imad Saeed (2009): "The extent of the impact of applying strategic management accounting methods on organizational performance and supporting the competitive strategy of business establishment - an applied analytical study", Cairo University, Facutly of Commerce, Journal of Accounting, Management and insurance, No. 77, pp. 347-389. Egypt.

[13]. Al-Zayni, Tamer Ibrahim Ali, (2019) "The entrance of features costs as a tool to rationalize the costs of building maire tugs", PhD thesis, Faculty of Commerce, Port Said University, Egypt.

[14]. Sayed, Sayed Abdel- Fattah (2010): “A proposed model for the integration of management accounting innovations to support enterprises to excel globally", an unpublished Ph.D. thesis in Accounting, Faculty of Commerce and Business Administrative, Helwen University, Egypt.

[15]. Arafa Nasr and Meligy Magdy, “The Impact of the Company’s Strategic on Strategic Management Accounting", a field study of the Egyptian environment, Benha University, Egypt, 2015.

[16].Al-Kashef, Mahmoud Youssef (2015): "Accounting the client as one of the strategic management accounting mwthods- trends and determinants of its application in Saudi companies- a field study", Journal of Accounting Thought, Ain Shams University, Faculty of Commerce, Accounting and Auditing Department, Volume 19, Number 1, p. 731 - 763, Egypt.

[17].Matar, Muhammad (2010): "Modern Trends in Financial and Credit Analysis", Methods, Tools and Practical Uses, Dar Wael for Publishing and Distribution, third edition, Amman, Jordan.

[18]. Nour, Saeed Khaled Muhammad (2015) "The role of management accounting using the value chain methods in achieving the strategic objectives of industrial companies listed on the Amman Stock Exchange, a field study, College of Gradute Studies, Zaqra University, Jordan.

[19].AlTarawneh Issa Mahmoud, Al-Thnaibat Hussam, Almomani Salam Nawaf, (2021), the impact of strategic management accounting techniques on achieving competitive advantage in the Jordianian public industrial companies, Academy of Accounting and Financial Studies Journal Volume 25, Special Issue 2, 2021

[20].Ayaz Yusuf ALTIN, Leyla AKGUN, Murat Kasimoglu, (2020), measuring the effect of strategic management accounting techniques on making investment decision of smes: eastern Anatolian case*, Istanbul Ticaret Universities Sosyal Bilimler Dergisi Y 1 1:19 Sayi:37 Bahar 2020/ 1 s.463-492.

[21].Thapayom Anucha, 2019 "Strategic Management Accounting Techniques and Organizational Sustainable Performance "Journal Of Modern Management Science 12(1) (2019) pp. 51 https://www.tci-thaijo.org/index.php/JMMS

[22].Akenbor, O.C. \& Okoye, E.I. (2012): "the Adoption of Strategic Management Accounting in Nigeria Manufacturing Firms", Affrev IJAH: An International Journal of Arts and Humanities. 1(3):270-287.

[23]. Al-Nawayseh, M.A.I. (2013): “The Extent of Applying Strategic Management Accounting Tools in Jordanian Banks", International Journal of Business and Management, 8(19): 32-44.

[24].Fawzia, R. (2011): "Strategic Management Accounting Techniques: Relationship with Business Strategic and Strategic Effectiveness of Manufacturing Organizations in Bangladesh", World Journal of Management, 3(2): 54-69.

[25].Ramljak, B. \& Rogosic, A. (2012): "Strategic Management Accounting Practices in Crotia”, the journal of International Management Studies, 7(2) 93-100.

[26].Mohammad, A.A. \& Jones, T. (2014): "Relationship between strategic management accounting techniques and profitability: a proposed model", Measuring Business Excellence, 18(3): 1-22.

[27]. Ohaka, John, (2019) "competitor cost assessment and profitability of quoted Nigerian manufacturing firms: a critical regression”, European Journal Of Accounting, Auditing and Finance Research, Vol. 7, ISSN: 2053-4049 (Online) See discussion, stats, and author profiles for this publication at: ttps://www.researchgate.net/publication/340117367

[28]. Karout, Racha, and Anjali Awasthi. "Improving Software Quality Using Six Sigma DMAIC-Based Approach: A Case Study”, Business Process Management Journal, Vol. 23, No. 4, 2017, Pp. 842-856, https://doi.org/10.1108/bpmj-02-2017-0028

[29].O.Ahmed, (2017)", integrated performance measurement system", Trakia Journal of science, Vol. 15, Suppl. 1, pp 145-151, 2017, Copyright (C) 2017 Trakia University, Available online at: http://www.unisz.bg

[30].Cadez, S., \& Guiding, C. (2008). An exploratory investigation of an integrated contingency model of strategic management accounting. Accounting, Organizations and Society. 33(7-8):836-863.

[31]. Langfield- Smith, K. (2008), "Strategic management accounting: how far have we come in 25 years?" Accounting, Auditing \& Accountability Journal, 21(2), pp. 204-28.

[32].Al-Maryani, M.A. H \& Sadik, H.H. (2012). Strategic Management Accounting Techniques in Romanian Companies: Some Survey Evidence. Procedia Economic and Finance, 3:387-396.

[33].Sakshi Sharma, (2017), Brand Valuation - Approaches and Methods, https://www.khuranaandkhurana.com/2016/12/10brand-valuation- $\quad$ approaches-and-methods,/?utm Source=Mondaq\&utm medium=syndication \&utm campaign=Linkedln-integration.

[34]. Turney, Peter, “Costumer Profitability”, Cost technology, 2005.

[35].Cinquini, L \& Tenucci, A. (2010). Startegic Management accounting and business strategy: a loose 
coupling? Journal of Accounting and Organizational Change, 6(2): 228-259.

[36]. Cost of Quality (COQ)", quality, retrived 8-12-2020.

[37]."What are Quality Costs?" my accounting course, Retrieved 8-12-2020. Edited.

\section{Websites}

- Kamal Youssef, (June 17, 2013), life cycle product design according to customer use, Arab Accountant, retrieved from the link. https://accdiscussion.com/acc6274.html.

- Aamer, Mahmoud, (October 20, 2019), Learn about Environmental Accounting, retrieved from the link: https://acc-jordan.blogspot.com/2019/10/1972.html

- https://www.hbrarabic.com/\%D8\%A7 Administrative Concepts / Benchmarking

- https://www.meemapps.com/term/5922217f09bd0304007ee94c/Customer\%20Value-Customer Value 